\title{
Grand Challenges in Sustainable Intensification and Ecosystem Services
}

\author{
Leslie G. Firbank ${ }^{1 *}$, Simon Attwood ${ }^{2,3}$, Vera Eory ${ }^{4}$, Yiorgos Gadanakis ${ }^{5}$, \\ John Michael Lynch ${ }^{6}$, Roberta Sonnino ${ }^{7}$ and Taro Takahashi, \\ ${ }^{1}$ School of Biology, University of Leeds, Leeds, United Kingdom, ${ }^{2}$ Bioversity International, Maccarese, Italy, ${ }^{3}$ School \\ of Environmental Sciences, University of East Anglia, Norwich, United Kingdom, ${ }^{4}$ Land Economy, Scotland's Rural \\ College (SRUC), Edinburgh, United Kingdom, ${ }^{5}$ School of Agriculture, Policy and Development, University of Reading, \\ Reading, United Kingdom, ${ }^{6}$ Atmospheric, Oceanic and Planetary Physics, University of Oxford, Oxford, United Kingdom, \\ ${ }^{7}$ School of Geography and Planning, Cardiff University, Cardiff, United Kingdom, ${ }^{8}$ Bristol Veterinary School, University \\ of Bristol, Bristol, United Kingdom, ${ }^{9}$ Sustainable Agriculture Sciences Department, Rothamsted Research, Okehampton, \\ United Kingdom
}

Keywords: safe and just operating space, UN Sustainable Development Goals, land use, place-based, food security

Arguably the greatest grand challenge for humankind is to keep the biosphere within its safe and just operating space, providing sufficient resources to meet people's needs without exceeding the Earth's capacity to supply them (Raworth, 2012). "Safe" is defined in terms of keeping planetary environmental processes, through mechanisms such as climate regulation and improved nutrient cycles, within limits over the long term (Rockstrom et al., 2009). "Just" is increasingly being interpreted in terms

\section{OPEN ACCESS}

Edited and Reviewed by: Ben Alex Woodcock, Centre for Ecology \& Hydrology, United Kingdom

*Correspondence: Leslie G. Firbank l.firbank@leeds.ac.uk

Specialty section: This article was submitted to Sustainable Intensification and Ecosystem Services, a section of the journal Frontiers in Sustainable Food Systems

Received: 29 January 2018 Accepted: 13 March 2018 Published: 28 March 2018

Citation: Firbank LG, Attwood S, Eory V Gadanakis Y, Lynch JM, Sonnino $R$ and Takahashi T (2018) Grand

Challenges in Sustainable Intensification and Ecosystem

Services.

Front. Sustain. Food Syst. 2:7. doi: 10.3389/fsufs.2018.00007 of meeting the UN Sustainable Development Goals, with targets addressing various forms of equity as well as biophysical needs (Griggs et al., 2013). Keeping the biosphere within the operating space requires that we produce the food we need, along with the ecosystem and socioeconomic goods and services we require (Garnett et al., 2013). By definition, achieving this challenge also means achieving the sustainable intensification (SI) of agriculture, whereby more food is produced from the same area of land (or water), with reduced or reversed negative environmental impacts accompanied by a range of positive societal and environmental co-benefits. SI is variously considered as a goal (Royal Society, 2009), a process (Firbank et al., 2013), a trade-off between economic production activity and ecological performance (Gadanakis et al., 2015), or a suite of interventions (Godfray and Garnett, 2014).

Is this challenge achievable? The jury is out. There are growing calls for dramatic increases in food production (Bernard and Lux, 2017) alongside grave concerns around the environmental impacts of agriculture on biodiversity (Maxwell et al., 2016), climate change (Whitfield et al., 2018), ecosystem services (Dobson et al., 2006), and continued food production (Smith et al., 2016). But people are starting to provide some tentative answers, suggesting that it is possible to stay within the safe and just operating space, as long as certain changes to the agrifood system are put in place. For instance, Mauser et al. (2015) suggested that improved crop management and market mechanisms could make the need to use more land to meet demand for biomass unnecessary. Muller et al. (2017) have asked whether organic farming could feed the world, while at the same time meet a range of environmental sustainability objectives. They sought to answer this by developing simulations of food supply and environmental impact under different scenarios of change in land use, levels of food waste, and potential impact of climate change on yields. Their answer was that organic farming will only feed the world if other aspects of the food system are changed at the same time. Finally, Eshel et al. (2017) have looked at the impacts of a shift to "sustainable" beef production in the US, concluding that a beef industry fed only by pastures and by-products of the food industry could generate around $43 \%$ of current levels of production and deliver substantial benefits to human health, depending on whether land used to grow livestock feed is reallocated to other crops. Such simulation studies are starting to bring about a degree of rigor to a debate that has otherwise been dominated more by heat than by light, simply by focusing 
attention on the assumptions behind the models. These conceal some rather large unknowns, including (i) the extent to which pest and disease control on organic land is subsidized by pesticide applications in the surrounding landscape; (ii) the scale of natural capital (NC) needed to help mitigate increasing climate volatility, where NC is defined as the world's stock of natural assets needed to sustain food production; and (iii) the extent to which soil management for food production can provide carbon sequestration. It is also a challenge to reach some form of consensus on the meaning and measurement of agricultural sustainability. Musumba et al. (2017) proposed a framework for farm-scale sustainability assessments that include elements of social justice, NC, and food security.

Of course, the selection of appropriate indicators is a long way from ensuring sustainable agriculture. Farmers need to gain enough value from their social and ecosystem benefits to adopt sustainable farming methods, and their choices will depend on social, economic, environmental, and regulatory context (de Oliveira Silva et al., 2016); in particular, they will need to maintain soil function and resilience (Schiefer et al., 2016). However, evidence of farming practices that simultaneously benefit food production and environment (Pywell et al., 2015) does not ensure the wide uptake of such practices: institutional innovation may be needed (Schut et al., 2016) as well as actions promoting behavioral and attitudinal change by both farmers (Moran et al., 2013) and the public (Barnes et al., 2016), many of whom are risk-averse. Sustainable landscape and catchment management is more complex again, as it is delivered by balancing different land and water uses and users across the area, either in terms of total amounts (Hodgson et al., 2010) or through spatially explicit allocation of land uses (Panagopoulos et al., 2012; Tscharntke et al., 2012; Landis, 2017). Dearing et al. (2014) examined interactions among a range of food and environmental indicators from two areas of China and concluded that increases in food production have pushed water quality beyond safe limits. While there may have been agricultural intensification, this was not achieved in an environmentally sustainable manner, which is now recognized (Liu et al., 2016).

The situation is further complicated by the reality of highly globalized value chains, the resultant transfers of value, nutrients, and pollutants as well as embedded carbon, energy, water, and labor. Adding to this, the relationships between rural, peri-urban, and urban agrifood systems are rapidly changing (Battersby, 2017). Throughout the twentieth century, the challenge of feeding a growing and increasingly concentrated population led to more enclosure of agricultural land, as part of both an ideological and a physical separation between rural (intensive) production systems and urban (mass) consumption spaces (Marsden and Sonnino, 2012). Since

\section{REFERENCES}

Barnes, A. P., Lucas, A., and Maio, G. (2016). Quantifying ambivalence towards sustainable intensification: an exploration of the UK public's values. Food Secur. 8, 609-619. doi:10.1007/s12571-016-0565-y

Battersby, J. (2017). MDGs to SDGs - new goals, same gaps: the continued absence of urban food security in the post-2015 global development agenda. Afr. Geogr. Rev. 36, 115-129. doi:10.1080/19376812.2016.1208769

Bernard, B., and Lux, A. (2017). How to feed the world sustainably: an overview of the discourse on agroecology and sustainable intensification. Reg. Environ. Change 17, 1279-1290. doi:10.1007/s10113-016-1027-y the beginning of this century, however, the unfolding of a range of complex and cross-scale social and environmental challenges, including resource depletion, climate change, food price volatility, and widening socio-inequalities, is making many dichotomies seem obsolete: production vs. consumption, rural vs. urban, and waste vs. resource, to name a few. Current policy and theoretical debates are focusing on the networked interdependencies between the city and the countryside as a fulcrum for innovative and more systemic, place-based and integrated development models (Sonnino et al., 2016). Paradigms such as "the circular economy" are increasingly used to give visibility to a new and normative urban-rural context that holds the potential to activate more metabolic flows of resources, knowledge, and skills (Geissdoerfer et al., 2017). There are crucial governance questions emerging in relation to the formation and stability of such urban-rural (regional) spaces. Importantly, intervention can be initiated at all major points of the supply chain (Eory et al., 2018): thus there is an inevitable need to address systemic change at all levels, including producers, manufacturers, distributors, and consumers (Macfadyen et al., 2015). These questions also apply to SI, because food security will not be achieved without resolving the inequities in distribution as well as the quantities and types of food products we demand (Godfray and Garnett, 2014). Tilman and Clark (2014) suggested that limiting global trends toward diets high in refined sugars, fats, oils, and red meat could significantly reduce food system greenhouse gas emissions (see also Hallstrom et al., 2015), while also improving human health. Springmann et al. (2017) have explored how such a change in consumption patterns might be brought about by modeling the potential emissions mitigation resulting from greenhouse gas taxes on food products. Such approaches have often proved controversial, not least because sustainability encompasses numerous notions beyond climate change and human health, which are an important part of the debate and must be given due consideration when facing problems of this scale.

Overall, then, achieving SI of agriculture within the global safe and just operating space is about finding the right balance between the needs of the present and future, the local and the global, the producer and the consumer, and the provider and the user of ecosystem services. This is a task for all consumers, producers, businesses, and policy makers. We trust that this journal will provide a valuable space for sharing evidence, ideas, and best practice.

\section{AUTHOR CONTRIBUTIONS}

LF is lead author. All other authors provided intellectual input, text, and edits.

de Oliveira Silva, R. D., Barioni, L. G., Hall, J. A. J., Matsuura, M. F., Albertini, T. Z., Fernandes, F. A., et al. (2016). Increasing beef production could lower greenhouse gas emissions in Brazil if decoupled from deforestation. Nat. Clim. Change 6, 493-497. doi:10.1038/nclimate2916

Dearing, J. A., Wang, R., Zhang, K., Dyke, J. G., Haberl, H., Hossain, M. S., et al. (2014). Safe and just operating spaces for regional social-ecological systems. Glob. Environ. Change 28, 227-238. doi:10.1016/j.gloenvcha.2014.06.012

Dobson, A., Lodge, D., Alder, J., Cumming, G. S., Keymer, J., McGlade, J., et al. (2006). Habitat loss, trophic collapse, and the decline of ecosystem services. Ecology 87, 1915-1924. doi:10.1890/0012-9658(2006)87[1915:HLTCAT] 2.0.CO;2 
Eory, V., Pellerin, S., Garcia, G. C., Lehtonen, H., Licite, I., Mattila, H., et al. (2018). Marginal abatement cost curves for agricultural climate policy: state-of-the art, lessons learnt and future potential. J. Clean. Prod. 182, 705-716. doi:10.1016/ j.jclepro.2018.01.252

Eshel, G., Shepon, A., Shaket, T., Cotler, B. D., Gilutz, S., Giddings, D., et al. (2017). A model for 'sustainable' US beef production. Nat. Ecol. Evol. 2, 81-85. doi:10.1038/s41559-017-0390-5

Firbank, L., Elliott, J., Drake, B., Cao, Y., and Gooday, R. (2013). Evidence of sustainable intensification among British farms. Agric. Ecosyst. Environ. 173, 58-65. doi:10.1016/j.agee.2013.04.010

Gadanakis, Y., Bennett, R., Park, J., and Areal, F. J. (2015). Evaluating the sustainable intensification of arable farms. J. Environ. Manage. 150, 288-298. doi:10.1016/ j.jenvman.2014.10.005

Garnett, T., Appleby, M. C., Balmford, A., Bateman, I. J., Benton, T. G., Bloomer, P., et al. (2013). Sustainable intensification in agriculture: premises and policies. Science 341, 33-34. doi:10.1126/science.1234485

Geissdoerfer, M., Savaget, P., Bocken, N. M. P., and Hultink, E. J. (2017). The circular economy - a new sustainability paradigm? J. Clean Prod. 143, 757-768. doi:10.1016/j.jclepro.2016.12.048

Godfray, H. C. J., and Garnett, T. (2014). Food security and sustainable intensification. Philos. Trans. R. Soc. B Biol. Sci. 369, 20120273. doi:10.1098/rstb. 2012.0273

Griggs, D., Stafford-Smith, M., Gaffney, O., Rockstrom, J., Ohman, M. C., Shyamsundar, P., et al. (2013). Sustainable development goals for people and planet. Nature 495, 305-307. doi:10.1038/495305a

Hallstrom, E., Carlsson-Kanyama, A., and Borjesson, P. (2015). Environmental impact of dietary change: a systematic review. J. Clean Prod. 91, 1-11. doi:10.1016/j.jclepro.2014.12.008

Hodgson, J. A., Kunin, W. E., Thomas, C. D., Benton, T. G., and Gabriel, D. (2010). Comparing organic farming and land sparing: optimizing yield and butterfly populations at a landscape scale. Ecol. Lett. 13, 1358-1367. doi:10.1111/j.1461-0248.2010.01528.x

Landis, D. A. (2017). Designing agricultural landscapes for biodiversity-based ecosystem services. Basic Appl. Ecol. 18, 1-12. doi:10.1016/j.baae.2016.07.005

Liu, X. J., Vitousek, P., Chang, Y. H., Zhang, W. F., Matson, P., and Zhang, F. S. (2016). Evidence for a historic change occurring in China. Environ. Sci. Technol. 50, 505-506. doi:10.1021/acs.est.5b05972

Macfadyen, S., Tylianakis, J. M., Letourneau, D. K., Benton, T. G., Tittonell, P., Perring, M. P., et al. (2015). The role of food retailers in improving resilience in global food supply. Glob. Food Secur. 7, 1-8. doi:10.1016/j.gfs.2016.01.001

Marsden, T., and Sonnino, R. (2012). Human health and wellbeing and the sustainability of urban-regional food systems. Curr. Opin. Environ. Sustain. 4, 427-430. doi:10.1016/j.cosust.2012.09.004

Mauser, W., Klepper, G., Zabel, F., Delzeit, R., Hank, T., Putzenlechner, B., et al. (2015). Global biomass production potentials exceed expected future demand without the need for cropland expansion. Nat. Commun. 6, 8946. doi:10.1038/ ncomms 9946

Maxwell, S., Fuller, R. A., Brooks, T. M., and Watson, J. E. M. (2016). The ravages of guns, nets and bulldozers. Nature 536, 143-145. doi:10.1038/536143a

Moran, D., Lucas, A., and Barnes, A. (2013). Mitigation win-win. Nat. Clim. Change 3, 611-613. doi:10.1038/nclimate1922

Muller, A., Schader, C., El-Hage Scialabba, N., Brüggemann, J., Isensee, A., Erb, K.-H., et al. (2017). Strategies for feeding the world more sustainably with organic agriculture. Nat. Commun. 8, 1290. doi:10.1038/s41467-017-01410-w
Musumba, M., Grabowski, P., Palm, C., and Snapp, S. (2017). Guide for the Sustainable Intensification Assessment Framework. KS, USA: Kansas State University.

Panagopoulos, Y., Makropoulos, C., and Mimikou, M. (2012). Decision support for diffuse pollution management. Environ. Modell. Softw. 30, 57-70. doi:10.1016/j. envsoft.2011.11.006

Pywell, R. F., Heard, M. S., Woodcock, B. A., Hinsley, S., Ridding, L., Nowakowski, M., et al. (2015). Wildlife-friendly farming increases crop yield: evidence for ecological intensification. Proc. R. Soc. B Biol. Sci. 282, 20151740. doi:10.1098/ rspb.2015.1740

Raworth, K. (2012). Planetary Boundaries and Social Boundaries: Defining a Safe and Just Operating Space for Humanity. Oxford: Oxfam.

Rockstrom, J., Steffen, W., Noone, K., Persson, A., Chapin, F. S., Lambin, E. F., et al. (2009). A safe operating space for humanity. Nature 461, 472-475. doi:10.1038/461472a

Royal Society. (2009). Reaping the Benefits: Science and the Sustainable Intensification of Global Agriculture. London: Royal Society, 72.

Schiefer, J., Lair, G. J., and Blum, W. E. H. (2016). Potential and limits of land and soil for sustainable intensification of European agriculture. Agric. Ecosyst. Environ. 230, 283-293. doi:10.1016/j.agee.2016.06.021

Schut, M., van Asten, P., Okafor, C., Hicintuka, C., Mapatano, S., Nabahungu, N. L., et al. (2016). Sustainable intensification of agricultural systems in the central African highlands: the need for institutional innovation. Agric. Syst. 145, 165-176. doi:10.1016/j.agsy.2016.03.005

Smith, P., House, J. I., Bustamante, M., Sobocka, J., Harper, R., Pan, G. X., et al. (2016). Global change pressures on soils from land use and management. Glob. Chang. Biol. 22, 1008-1028. doi:10.1111/gcb.13068

Sonnino, R., Marsden, T., and Moragues-Faus, A. (2016). Relationalities and convergences in food security narratives: towards a place-based approach. Trans. Inst. Br. Geogr. 41, 477-489. doi:10.1111/tran.12137

Springmann, M., Mason-D’Croz, D., Robinson, S., Wiebe, K., Godfray, H. C. J., Rayner, M., et al. (2017). Mitigation potential and global health impacts from emissions pricing of food commodities. Nat. Clim. Change 7, 69-74. doi:10.1038/nclimate3155

Tilman, D., and Clark, M. (2014). Global diets link environmental sustainability and human health. Nature 515, 518-522. doi:10.1038/nature13959

Tscharntke, T., Clough, Y., Wanger, T. C., Jackson, L., Motzke, I., Perfecto, I., et al. (2012). Global food security, biodiversity conservation and the future of agricultural intensification. Biol. Conserv. 151, 53-59. doi:10.1016/j. biocon.2012.01.068

Whitfield, S., Challinor, A. J., and Rees, R. M. (2018). Frontiers in climate smart food systems: outlining the research space. Front. Sustain. Food Syst. doi:10.3389/ fsufs.2018.00002

Conflict of Interest Statement: The authors declare that the research was conducted in the absence of any commercial or financial relationships that could be construed as a potential conflict of interest.

Copyright (C) 2018 Firbank, Attwood, Eory, Gadanakis, Lynch, Sonnino and Takahashi. This is an open-access article distributed under the terms of the Creative Commons Attribution License (CC BY). The use, distribution or reproduction in other forums is permitted, provided the original author(s) and the copyright owner are credited and that the original publication in this journal is cited, in accordance with accepted academic practice. No use, distribution or reproduction is permitted which does not comply with these terms. 